\title{
THE IMPLEMENTATION OF MANASARA-SILPASASTRA AS A FACTOR IN THE SELECTION OF THE POSITION OF PETIRTAAN DEREKAN IN THE COMPLEX OF NGEMPON TEMPLE, SEMARANG, CENTRAL JAVA
}

\section{Penerapan Manasara-Silpasastra sebagai Faktor yang Memengaruhi Pemilihan Letak Petirtaan Derekan dalam Kompleks Candi Ngempon, Semarang, Jawa Tengah}

\author{
Abednego Andhana Prakosajaya ${ }^{1 \mathrm{a}}$, Hot Marangkup Tumpal $\mathrm{S}^{1 \mathrm{~b}}$, Rizal Hendra Pratama ${ }^{1 \mathrm{c}}$ \\ ${ }^{1}$ Departemen Arkeologi, Fakultas Ilmu Budaya, Universitas Gadjah Mada \\ Jalan Sosiohumaniora, No. 1, Bulaksumur, Yogyakarta 55281, Indonesia \\ a abednego.andhana@mail.ugm.ac.id; bhot.marangkup.tumpal@mail.ugm.ac.id; \\ crizal.hendra.pratama@mail.ugm.ac.id
}

Received: 26/06/2020; revision: 10/07/2020-7/06/2021; accepted: 08/06/2021

Published online: 26/06/2021

\begin{abstract}
Abstrak
Terdapat beberapa petirtaan di Jawa Tengah yang merupakan bagian integral dari sebuah candi. Fenomena ini dapat dilihat pada tata ruang Candi Ngempon yang terletak tidak jauh dari Petirtaan Derekan. Penelitian ini bertujuan untuk menganalisis penerapan kitab Manasara-Silpasastra yang memengaruhi tata letak petirtaan dengan suatu candi sebagai satu bagian integral. Penelitian ini dilakukan dengan analisis data sekunder yang diperoleh dari studi pustaka dan wawancara. Data sekunder tersebut kemudian menjadi dasar dilakukannya crosscheck dengan melakukan pengamatan lapangan. Dari metode tersebut diperoleh kesimpulan bahwa tata ruang Pechaka dalam ManasaraSilpasastra diduga menjadi dasar pemilihan letak Candi Ngempon yang berada di sisi timur laut Petirtaan Derekan sehingga menunjukan adanya penerapan kitab Manasara-Silpasastra dalam kasus ini.
\end{abstract}

Kata Kunci: Petirtaan, Candi Ngempon, Tata Ruang.

\begin{abstract}
There are several petirtaans or bathing structures in Central Java that become an integral part of a temple complex. Such a phenomenon can be seen in the layout of Ngempon Temple and Petirtaan Derekan which are located close to each other. This research aims to analyze the implementation of the book of Manasara-Silpasastra in the layout of Petirtaan Derekan and Ngempon Temple as an integrated whole. The research was carried out by analyzing secondary data obtained from a literature review and interviews. The secondary data were corroborated with data obtained from field observations. Results of the analysis indicate that the layout of Pechaka in Manasara-Silpasastra might become the basis for the positioning of Ngempon Temple at the northeast of Petirtaan Derekan. This shows that the book of Manasara-Silpasastra might be implemented in the layout of the complex of Ngempon temple.
\end{abstract}

Keywords: Petirtaan, Ngempon Temple, Layout.

\section{INTRODUCTION}

Petirtaan or patirthan is a word originating from the Ancient Javanese word tirtha, which means 'water'. The prefix $p a-$ and the suffix -an were added to the word, resulting in a new word Patirthan, which means 'a holy or sacred bathing place or a pilgrimage place' (Zoetmulder, 1994, p. 1261). Petirtaan is essentially an integral part of a religious holy building of Hinduism or Buddhism. This is so because petirtaan is the place for a visitor to perform self purification before making a pilgrimage or 
performing the ritual of puja at a temple (Santiko, 2012, p. 22). The book of Manasara-Silpasastra explains one requirement for the position of a temple that symbolizes its holiness, which is that it has to be close to a spring, because water has the potential for cleaning, purifying, and fertilizing, and because a spring may function as the centre of worship (Sudaryati \& Adnyana, 2018, p. 111). Kramrisch (Sudaryati \& Adnyana, 2018, p. 111) stated that the locations of a religious complex as a whole and its nearby spring are more important than the position of the temple itself. This shows that the positions of the land and the spring become the main consideration in the selection of a place where a temple will be built (Sudaryati \& Adnyana, 2018, p. 111). The spring structure in a religious complex has to be built first. The temple has to be built close to the spring because water has a very important role in human life. Gods will not be willing to visit a holy place that has no water pool (Sudaryati \& Adnyana, 2018, p. 111). Water as the symbol of holiness is mentioned in the book of Adiparwa. The book states that water or tirtha has the function of cleaning all mala (dirt), which is called samanta pancaka tirtha. Water may clean all the mala of a king who dies in a war. If the king takes a bath using the water from a holy place, his mala will be gone and he will go to the paradise (Sudaryati \& Adnyana, 2018, P. 111)

Petirtaans, which have a connection with temples are often mythologically related to the symbol of mountain manifested in the forms of temple and sea. This shows that a petirtaan is related not only to the physical aspect, i.e. sea, which evaporates to form clouds, which turn to be rain, which fertilizes soil, but also to the preservation of sanctity, which is the function of a petirtaan itself (Sumerata, 2013, p. 222). Nareswara (1993) in his thesis titled "Pengertian dan Fungsi Petirtaan pada Masa Klasik di Jawa" ("The
Conception and Function of Petirtaans in the Classical Era in Java") explained the function of petirtaans by referring to the conceptions of petirtaan developed in India and Java. However, like other studies that deal with petirtaans in Java, his study does not specifically discuss the selection of the position of petirtaan based on the book of Manasara-Silpasastra.

There may be other factors that have some influence on the selection of the position of a petirtaan from the practical and efficiency perspectives. A spring may be selected to be developed to be a petirtaan because its location is ideal and the water is abundant (Sumerata, 2013, p. 221), However, certain layout rules, like the one explained in the book of ManasaraSilpasastra or Vastupurusamandala from India, still become a key factor in the selection of the position of a petirtaan. Due to this, this research aims to find out whether the selection of the position of the petirtaan in temple complexes build during the classical period of Central Java was based on the book of Manasara-Silpasastra. The objects considered to be ideal to be investigated in the case study here are Ngempon Temple and Petirtaan Derekan, which are located in Semarang Regency, Central Java. Both sites are close to each other. The layout of the two sites and factors underlying the selection of their locations can be analyzed comprehensively.

Rahadian and Fery (2015) have investigated the typology of petirtaans built in the classical periods of Java and Bali. They established five typologies based on the petirtaans' typomorphology, layout, depth, locations, and water types. Based on its typomorphology, Petirtaan Derekan belongs to the category of 'rectangular petirtaan temple'. Based on its layout, Petirtaan Derekan belongs to the category of 'stand separately'. Based on its depth, Petirtaan Derekan belongs to the category of 'deep'. Based on its location, Petirtaan Derekan belongs to the category of 'above a 
spring. Based on its water type, Petirtaan Derekan belongs to the category of 'hot water'. Based on its bhauma or spring type (according to an Indian classification), the water in a petirtaan belongs to the type of audhiba, in which the water comes out with pressure from a spring (Krishnamurthy, 1996, pp. 329-330). Besides Rahardian and Fery, Degroot (2008) has also conducted a study, in the form of short survey, on petirtaans in Central Java. Degroot did not analyze Petirtaan Derekan, but he concluded that the Indian influence on Central Javanese petirtaans is minimal. The Indian influence can be seen more in East Javanese petirtaans. Degroot (2008, p. 66) studied the typology of classical petirtaans in Central Java based on their geographical conditions. He doubted the function of petirtaans in Central Java as the place for self purification before entering a temple. Degroot emphasized that the positioning of a petirtaan is fully based on geographical consideration.

Besides Rahardian and Fery, Nareswara (1993) has also studied the typology of petirtaans. Nareswara classified several types of petirtaans and the relationship between the types of petirtaans and their functions. He classified petirtaans into three categories, namely, the petirtaan close to a temple, the petirtaan related to the layout of a town, and the petirtaan close to a kraton (Javanese palace). These three categories are related to the function of petirtaans in its connection with the existence of a holy building close to them and the hermitage inside them that stands separately. Meanwhile, petirtaans related to the layout of a town or located close to a kraton are more related to the conception of cosmology that the capital city of a kingdom functions not only as the political centre, but also the magical power of the kingdom (Nareswara, 1993, p. 117).

Manasara-Silpasastra is the book used by the Indian community as a reference to determine all things related to architecture including the architecture of petirtaans and other holy buildings. The book of Manasara-Silpasastra consists of 60 chapters that discuss all building types, the layout of a building, furniture, ornaments, clothes, sculpture, and the principles of selecting the location of a building (Acharya, $1934 b$, p. 1). Actually, it is still debated whether the book of Manasara-Silpasastra was used as a reference to build temples in Indonesia. The implementation of the book in the selection of the location of a temple has been discussed by some scholars, who have recommended that it be studied, but this has never been done due to the assumption that geographical differences between Indonesia and India are too big (Mundarjito, 1993, pp. 239-243). Another source stated that the book of ManasaraSilpasastra was never fully implemented in Indonesia, especially during the Majapahit era, because the book was adapted in such a way to the development of knowledge and skills in the building of religious structures during the classical period in Indonesia so that in the Majapahit or late classical period, Manasara Silpasastra was not used anymore or a new book resulting from an adaptation of the book of Manasara-Silpasastra with the Indonesian culture and environment appeared (Munandar, 2015, pp. 131-133).

A research based on ManasaraSilpasastra has been carried out to calculate the number of workers building a temple (Munandar, 2015, pp. 142-152). The result of the research is an estimated formula for calculating the number of workers building a temple based on the temple' dimensions. Another research based on ManasaraSilpasastra has been conducted by Hidayah, Suryani, and Antariksa (2016). The results of their research show that there is a connection between the proportions of Angka Tahun Temple and Sawentar Temple in Blitar and that of Santika in ManasaraSilpasastra (Hidayah, Suryasari, \& Antariksa, 2016, p. 9). Unlike the results of some previous researches, the results of the 
analysis of the height and width of the gate of Gebang temple show that they are different from the ones specified in Manasara-Silpasastra. Therefore, it can be concluded that not all the temples in Indonesia were built according to the principles of building a holy structure adopted in India (Indradjaja, 2000, p. 73). Considering all this, it is hoped that this research will provide some contribution to the development of discourse on the implementation of the book of ManasaraSilpasastra in Indonesia.

The principles of laying out a religious complex that are used for the analysis in this research are taken from one section in Chapter 7 of the book of ManaraSilpasastra, which discusses the layout of a religious complex. Line 60 in the section states that a petirtaan and a general place of worship has the layout of Pechaka. Lines 5759 explain that in the layout of Pechaka, an area is divided into four squares and delimited by eight lines. The squares are located in the cardinal directions of North, South, East, and West respectively. Each of the directions corresponds to a certain god (Acharya, 1934a, p. 428). In the section of the layout of Pechaka, it is stated that Shiva is placed in the northeast, Agni in the southeast, Pavana in the southwest, and Gagana in the northwest. The analysis in this research is conducted to find out whether the layout of Pechaka was implemented in the positioning of Petirtaan Derekan in the complex of Ngempon Temple.

\section{METHOD}

This research applied the method of inductive reasoning, which was started by making an observation of the layout of the complex of Ngempon Temple, specifically the positioning of Petirtaan Derekan in the complex. Results of the observation were analyzed with the theories related to some previous researches, namely the theory of the layout of temples built during the Central Javanese period and the theory of petirtaans as an integral part of a temple complex, which has been mentioned above. These two theories become the basis for formulating conclusions and developing new theories based on the results of this case study.

For collecting data, two methods, archaeological survey and literature review, were applied. The data collection with the method of archaeological survey was conducted by (i) making an observation and exploration on the site and the surrounding environment and (ii) making a short interview with the caretaker to obtain some information about the site. Documentation was then conducted by recording visual data so that the data could be analyzed more deeply. The documentation used an appropriate scale so that the measurement can be recorded correctyly according to archaeological research principles.

The data collection with the method of literature review was conducted by reviewing various references considered to be relevant to the answering of the research questions.

\section{RESULTS AND DISCUSSION}

\section{Description of the Site}

Administratively Ngempon Temple is located in Ngempon Village, Bergas Subdistrict, Semarang Regency, Central Java Province. Astronomically Ngempon Temple is located at $110^{\circ} 26^{\prime} 40^{\prime \prime}$ East Longitude and $07^{0} 11^{\prime} 34^{\prime \prime}$ South Latitude. The area is 2,250 $\mathrm{m}^{2}$. Ngempon Temple is more or less $50 \mathrm{~m}$ north of Kedung Dowo River, which is also known as Tempuran River. The temple is located at the northern side of the stream valley of Kedung Dowo River, so that topographically the site of the temple tends to be higher at the northern side. The temple is surrounded by rice fields (Figure 1). Based on its architectural features, Ngempon Temple can be categorized as a Hindu temple built in the $8^{\text {th }}-9^{\text {th }}$ century (BPCB Jawa Tengah, 2014, p. 3). Ngempon Temple (Figure 2) is a temple complex that consists 


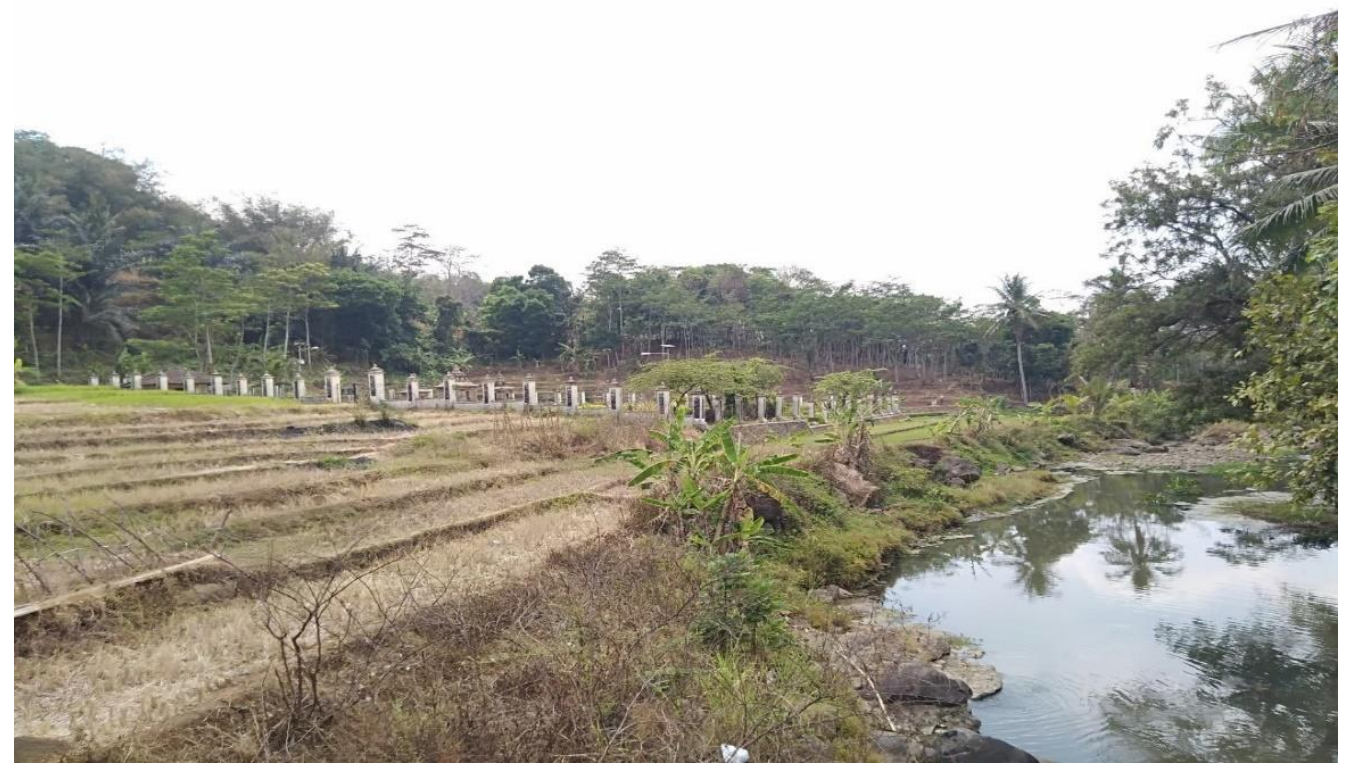

Figure 1. Rice fields and Kedung Dowo River, which are close to Ngempon Temple (Source: Prakosajaya and team, 2020).

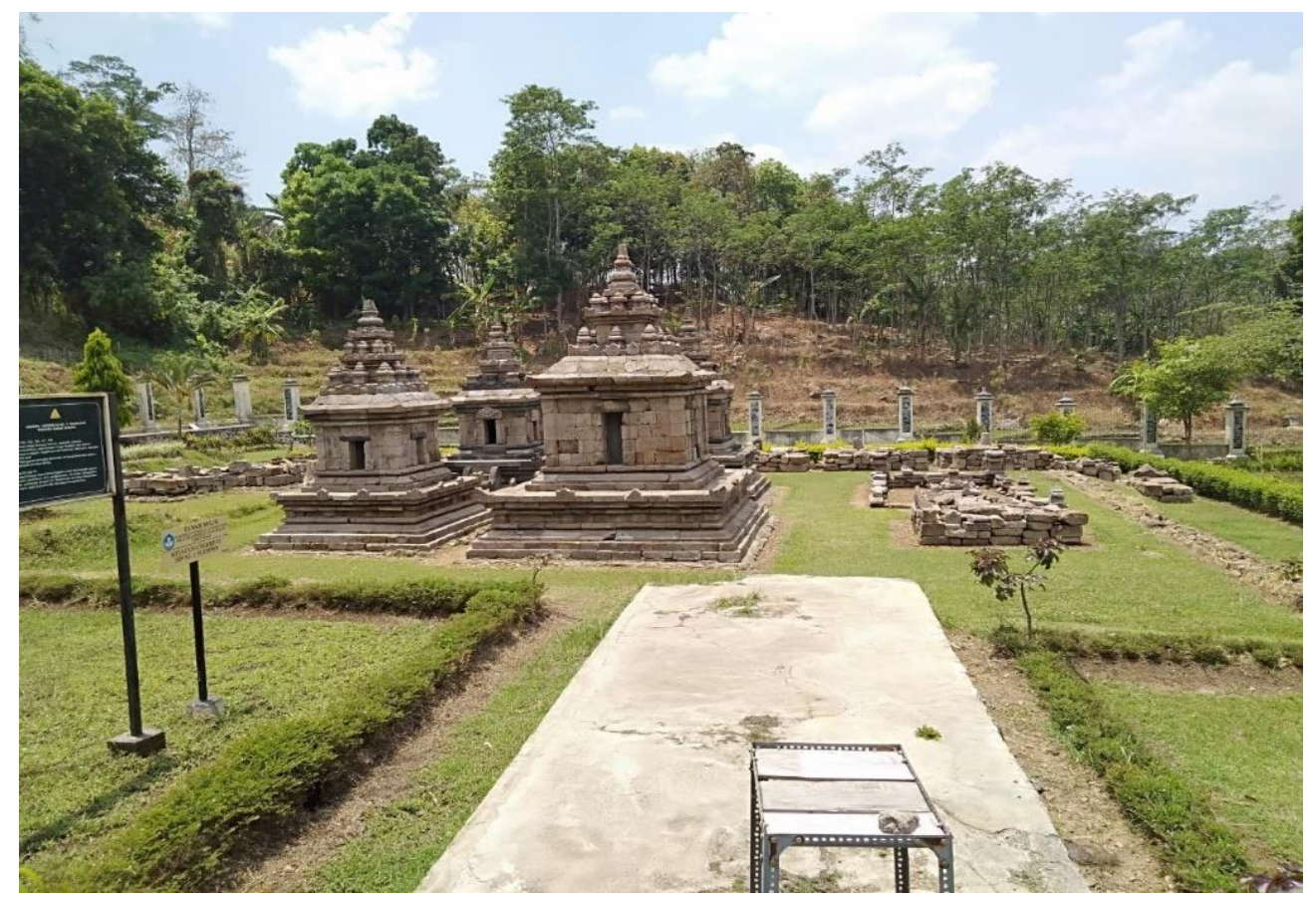

Figure 2. Ngempon Temple (Source: Prakosajaya and team, 2020).

of five perwara (accompanying) temples and one main temple. The main temple faces east. Two perwara temples at the northern and southern sides of the main temple also face east. Meanwhile, the other perwara temples face west and the other two perwara temples and the main temple. At a glance, the layout of Ngempon Temple is identical to that of Prambanan Temple. The dimensions of the main temple are $3.77 \mathrm{~m} \mathrm{x}$ $3.87 \mathrm{~m}$ with the height of $4.45 \mathrm{~m}$ while those of the perwara temples that have been restored are $2.85 \mathrm{~m} \times 2.85 \mathrm{~m}$ with the height of $4.15 \mathrm{~m}$. The four temples that have been 


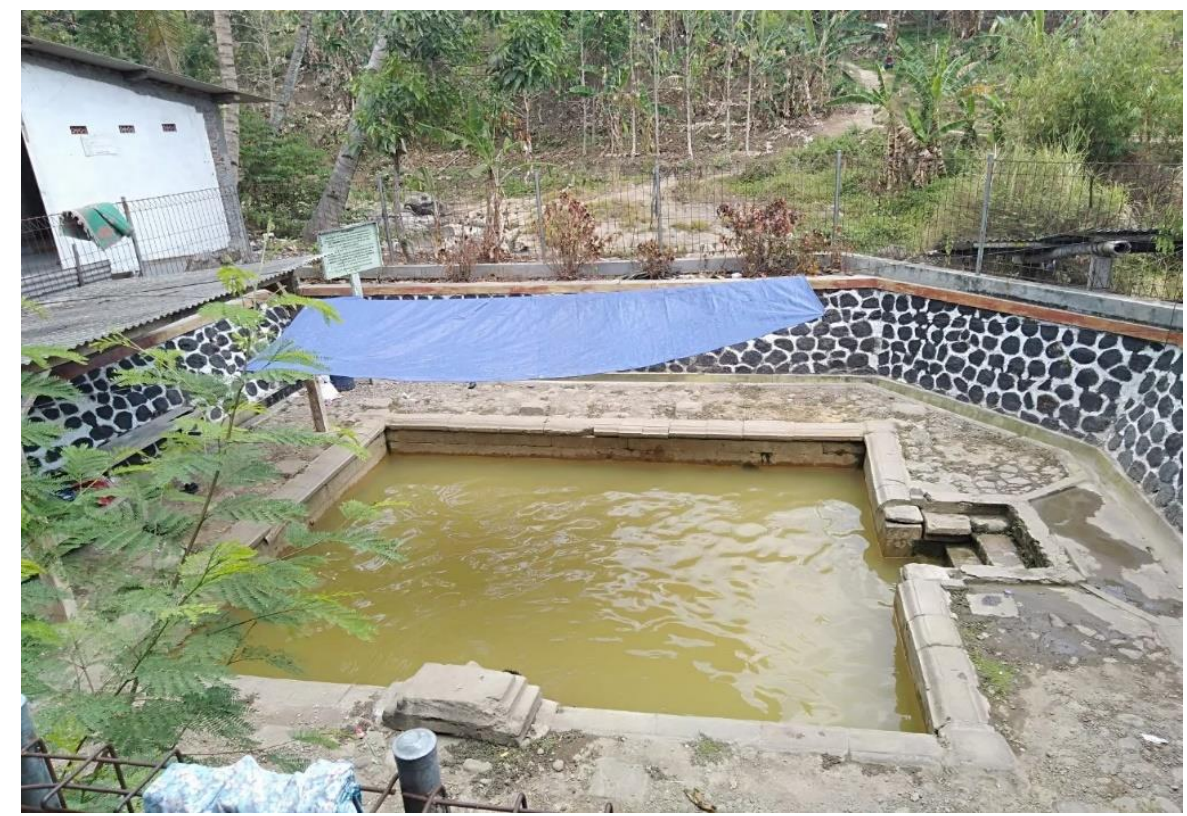

Figure 3. Petirtaan Derekan (Source: Prakosajaya and team, 2020).

restored are decorated with various ornaments depicting flora and fauna. An ornament of swan can be seen at the outer corner of the stairs leading to the door of the main temple. Ornaments of flowers and flowers with a strand of pearls can be seen on the temple's foot, and ornaments of flowers with various fauna including goats can be seen on the temple's body. Ornaments of genta and kinara kinari can be seen on the niches of the main and perwara temples. Ngempon Temple was in ruins when it was found. The temple was restored step by step in 2006 and 2009 by the Central

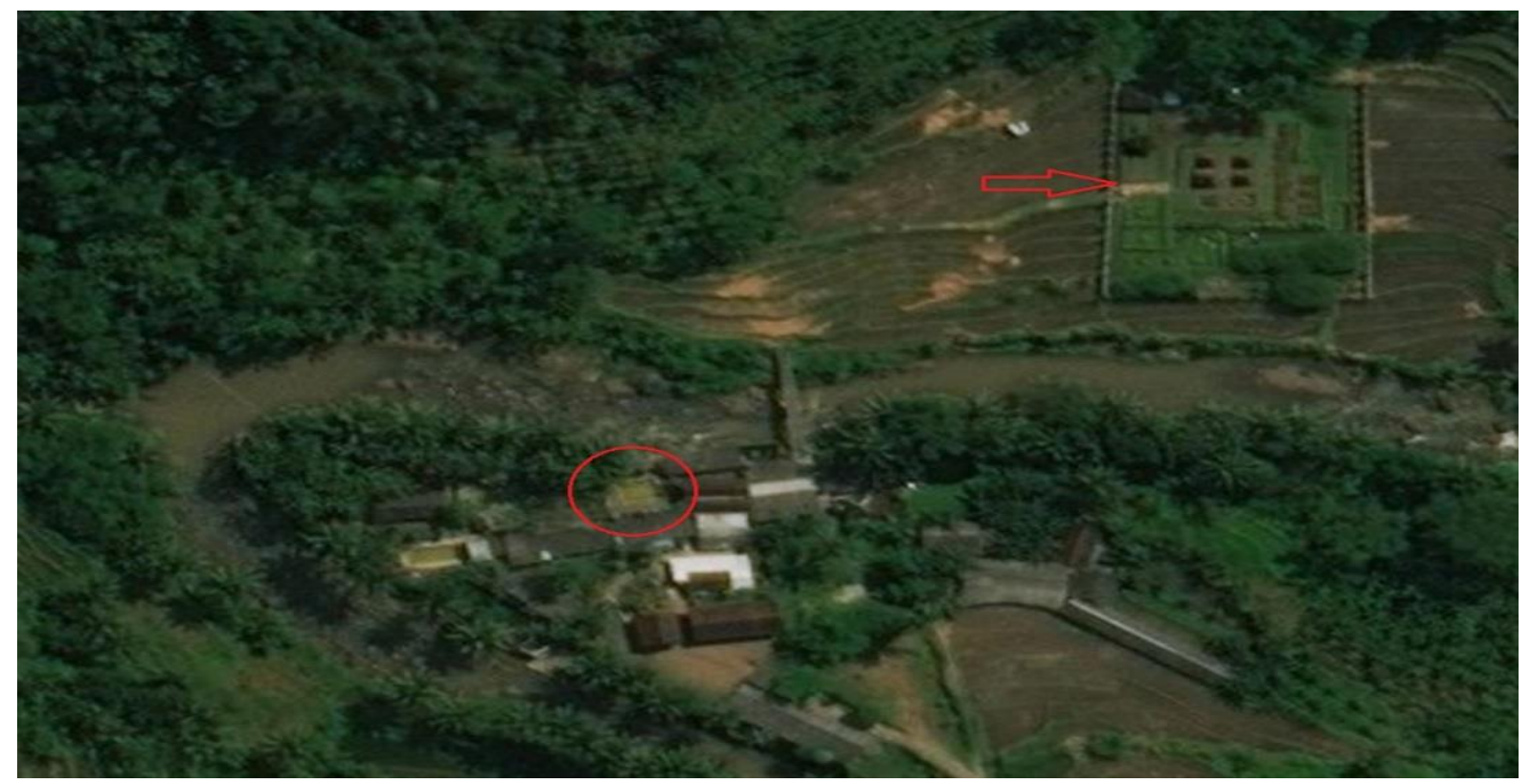

Figure 4. An aerial photo of the complex of Ngempon Temple (red arrow) and Petirtaan Derekan (red circle) (Source: Google Maps with some modification, 2020). 
Java Office of Cultural Heritage Preservation. The main temple and the perwara temple north of it were restored in 2013. The two perwara temples that face west and the main temple were excavated in 2014 to find their peripih (amulets or talismans put in a container). However, the peripih could not be found. During the restoration process, the foundation of the four temples was reinforced with cement concrete for conservation purposes BPCB Jawa Tengah, 2009, p. 7).

The petirtaan related to the layout of Ngempon Temple is Petirtaan Derekan, which is located $100 \mathrm{~m}$ southwest of the temple. Petirtaan Derekan (Figure 3) is a square-shaped bathing pool found in 2009. This petirtaan is made of andesite stone and in the middle of it there is a hot spring whose water contains sulphur. The length of the petirtaan is $512 \mathrm{~cm}$, its width is $514 \mathrm{~cm}$, and its depth is 150 . The pool wall is made of six layers of andesite stone. The stairs leading to the pool gate are placed at the eastern side of the petirtaan. There is a niche at the southern side of the petirtaan. There used to be a statue of Ganesha inside the niche. A couple of statues were found in the middle of the pool. The statues cannot be identified and interpreted as character figurines. Now the three statues are being stored in the Central Java Office of Cultural Heritage Preservation. Around the petirtaan, twelve bases were found and they have been left in situ. Their dimensions are $30 \mathrm{~cm}$ x $30 \mathrm{~cm}$ (Balai Arkeologi Yogyakarta, 2017, p. 54). The bases indicate that petirtaan Derekan used to have roof that was made of wood or another perishable material. Petirtaan Derekan is a living monument, which can be seen from the fact it is used by some Hindu people to perform a ceremony twice a year. The reutilization of Petirtaan Derekan as a place of worship shows that its current function and use are different from its original ones. Therefore, reconstruction using the method of ethnoarchaeology will not be possible. Petirtaan Derekan and
Ngempon Temple are relatively close to each other (Figure 4). Both are separated by a river and connected by a bridge as described earlier.

\section{Data Analysis}

As can be seen on figure 5, Ngempon Temple is located in the southeast of Petirtaan Derekan. Considering the position of Petirtaan Derekan relative to Ngempon Temple, in which Petirtaan Derekan is placed at the axis, it can be seen that such positioning conforms with the layout of Pechaka as specified in the book of Manasara-Silpasastra (Figure 2). This is supported by the positioning of the place for Shiva worship in the northeast area according to the layout of Pechaka. Like other temples in Indonesia, Ngempon Temple is a temple dedicated for Shiva worship, which is shown by the discovery of the statues of Shiva and Durga around the temple's foot (Ramelan et al., 2013, p. 59) and the statue of lingga-yoni in the ruins around the five perwara temples and the main temple. It is highly likely that these statues have been moved from their original place. The implementation of the layout of Pechaka for a public bathing structure in Petirtaan Derekan shows that this pertirtaan was used for the public and supports the opinion of Degroot (2008) that the function of petirtaans in Central Java was not the same as that of most of the petirtaans in India, which are strongly connected to the existence of a temple or a worship place. The implementation of the layout of Pechaka is not found in the complex of Ngempon Temple if the temple is seen as the axis. This might be due to the fact that Ngempon Temple was used as a worship place not for the public, but for only a certain community.

There are some problems in interpreting the concept of Pechaka as stated in the book Manasara-Silpasastra; the book does not clearly explain how to interpret the positioning of the god of Shiva (Isa) in the northeastern side. In the case of Petirtaan 


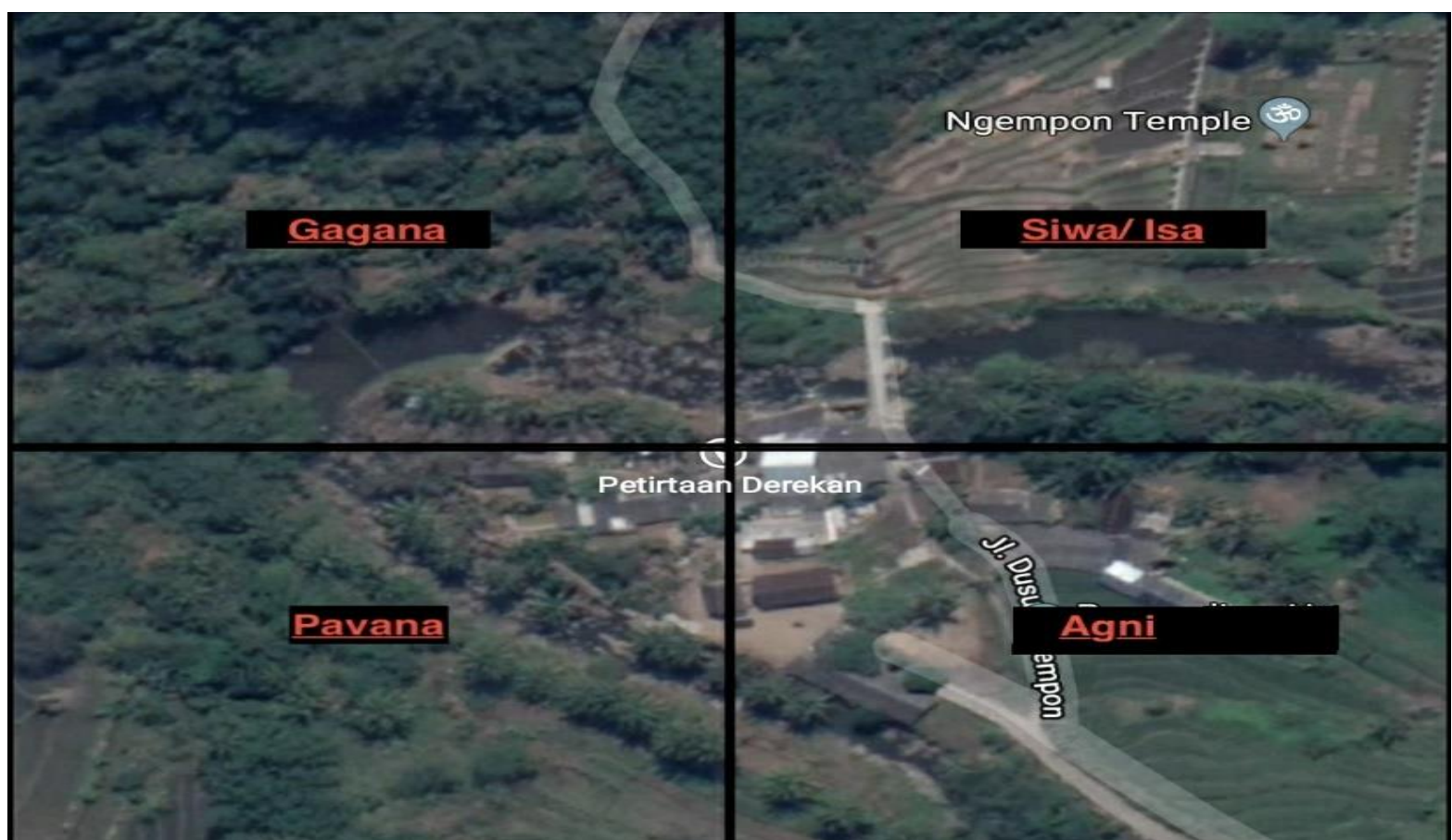

Figure 5. Illustration of the positioning of Petirtaan Derekan as the centre in the layout of Pechaka in which Petirtaan Derekan is in the axis and Ngempon Temple is in the square of Shiva /Isa (Source: Google Maps with some modification, 2020).

Derekan, the positioning of the god of Shiva in the northeastern side is manifested in the existence of Ngempon Temple as a temple for worshipping the god of Shiva, which is like the majority of other temples in Indonesia. Supposing that the complex of Ngempon Temple had been built according to the concept of Pechaka, besides a temple dedicated to the god of Shiva, there should be other places of worship for other gods, as specified in the concept of the layout of Pechaka, namely a place of worship for the god of wind (Pavana) in the southeast, a place of worship for the god of fire (Agni) in the southwest, and a place of worship for the god of sky (Gagana) in the northwest. The caretaker of Ngempon Temple said that there has been no discovery of structures, temple stones or other materials that may indicate the existence of classical artifacts outside the boundary fence of the existing archaeological site built by the Central Java Office of Cultural Heritage Preservation. However, the possibility of a discovery of new structures or materials related to the layout of Pechaka should not be ruled out, although such a possibility is little considering that the gods other than the god of Shiva were not popular in Java. The second problem is related to the discovery of the statue of Ganesha and the other two statues around Petirtaan Derekan. The discovery of these three statues breaks the notion that the concept of the layout of Pechaka is implemented in Petirtaan Derekan and that petirtaans in Central Java have a profane function. Regardless of the various existing problems and criticisms, the selection of the position of the petirtaan in the complex of Ngempon Temple is in line with the book of Manasara-Silpasastra although it is the layout of Petirtaan Derekan, not that of Ngempon Temple, that becomes the main consideration. This research did not find any implementation of the concept of the layout as specified in Manasara-Silpasastra in Ngempon Temple. Therefore, the analysis of the selection of the position of Petirtaan Derekan based on the concept of the layout of a holy structure as 
the axis needs to incorporate concepts of the layout of holy structures other than those specified in the book of ManasaraSilpasastra. However, other layout concepts and non-conceptual considerations, such as geographical and geomorphological factors, are not incorporated in the analysis here because they are not in line with the title and problems of this research.

The concept emphasized in India and Indonesia is that some saints visited petirtaans, causing the water to become holy and useful; the presence of the saints made the gods happy, so that they were willing to visit the petirtaans. (Nareswara, 1993, p. 55). Petirtaans that are close to a river are common in India. Kundas or holy pools have been built along Gangga River as an integral facilitys of a worship place or as a place of worship itself (Singh, 1994, pp. 217-223). Considering that water plays an important role in all of the Hindu ceremonies and rituals due to the belief that water is pure and can be seen as a form of worship for the gods (Krishnamurthy, 1996, p. 327), the positioning of Ngempon Temple at a place not far from a river and a petirtaan can be seen as an effort to strengthen the sanctity of Candi Ngempon, which is dedicated to the god of Shiva. This notion is against the theory that the selection of the location of a temple was based on such parameters as soil permeability, fertility, and absorption rate (Harriyadi, 2019,p. 134). These parameters are also taken from Manasara-Silpasastra. The spring factor was more important than the location factor. If a place in which a holy structure would be built did not have a spring, an artificial spring in the form of water pool could be built (Harriyadi, 2019, p. 134). Another evidence that the spring factor was more important than the location factor is the selection of the position of the temple in an area that is prone to landslides. The soil is volcanic and alluvial and the tilt angle of the land is $25 \%-45 \%$ (Zulaikah, 2020, p. 63-66). Building the temple on such a hillside is like challenging disasters, because when there is a landslide, the temple will be burried. This shows that the existence of a spring became the main factor in selecting the location of a holy building; although the location in which a holy building would be built was prone to disasters, the holy building would still be constructed as long as there was a spring close to it.

\section{CONCLUSION}

Ngempon Temple and Petirtaan Derekan are two cultural heritage sites built during the classical period of Central Java that show an integral layout. The two sites are integral parts of a complex of worship, which is line with the concept specified in the book of Manasara-Silpasastra. Results of the analysis show that the selection of the position of Petirtaan Derekan in the complex of Ngempon Temple was in line with the concept of the layout of Pechaka. The implementation of this layout is manifested in the selection of the position of Ngempon Temple in the northeast of Petirtaan Derekan. This shows that the temple is dedicated to Shiva (Isa) - as has been explained earlier, in the layout of Pechaka, the temple dedicated to Shiva is placed at the northeast. The layout of the complex of Ngempon Temple as a manifestation of the implementation of the concept of Pechaka indicates the Indian influence on Nusantara at least during the classical period of Central Java. This case study shows that the implementation of Manasara-Silpasastra in the layout of cultural heritage sites built in the Hindu Buddhist period is potential to study. This research involves only one case, so that the results cannot be used for generalization. However, they may provide an additional perspective and interpretation to the discourse on archaeology especially the Indian culture's influence on Nusantara in the Hindu-Buddhist period. The results of this research may become a basis for further researches that have a broader scope. Results 
of those further researches may be used for generalizing a pattern of the selection of the position of a petirtaan in a temple complex built in the Hindu-Buddhist period in Nusantara based on Manasara-Silpasastra.

\section{Acknowledgement}

We would like to express our gratitude to the supervisors of this research, namely Mrs. Niken Wirasanti, Mrs. Mahirta, and Mr. Dwi Pradnyawan, lecturers at the study program of Archaeology, the Faculty of Cultural
Sciences, Gadjah Mada University. We also would like to express our gratitude to the caretaker of Ngempon Temple and Umbul Temple. In his capacity as the resource person for this research, he provided some of the key data.

$* * * * * * *$

\section{REFERENCES}

Acharya, P. K. (1934a). Architecture of Manasara. New Delhi: Munshiram Manoharial.

Acharya, P. K. (1934b). Indian Architecture According to Mānasāra-Śilpaśāstra. New Delhi: Oriental Books Reprint Corporation.

Balai Arkeologi Yogyakarta. (2017). Laporan Peninjauan Arkeologi 2017: Temuan Baru di Kabupaten dan Kota Semarang serta Kabupaten Temanggung Provinsi Jawa Tengah. Yogyakarta. Tidak Diterbitkan.

BPCB Jawa Tengah. (2009). Laporan Termin 1 Pelestarian Dua Candi Perwara Kompleks Candi Ngempon, Semarang. Semarang. Tidak Diterbitkan.

BPCB Jawa Tengah. (2014). Laporan Konservasi Candi Ngempon, Kabupaten Semarang. Semarang. Tidak Diterbitkan.

Degroot, V. (2008). Ancient Bathing Places of Central Java: A Short Survey. Aziatische Kunst, 38(4), 62-68. https://doi.org/https://doi.org/10.1163/25431749-90000159

Harriyadi. (2019). Pertimbangan Pemilihan Lokasi Kompleks Candi Dieng. Amerta, Jurnal Penelitian dan Pengembangan Arkeologi, $\quad 37(2), \quad 123-138$. https://doi.org/https://doi.org/10.24832/amt.v37i2.123-138

Hidayah, N., Suryasari, N., \& Antariksa. (2016). Proporsi Bentuk Candi Angka Tahun dan Candi Sawentar di Blitar Jawa Timur. Jurnal Mahasiswa Jurusan Arsitektur, 4(4).

Indradjaja, A. (2000). Proporsi Tinggi Dan Lebar Pintu Masuk Candi Gebang. AMERTA, 20(1), 59-75. https://doi.org/https://doi.org/10.24832/amt.v20i1

Krishnamurthy. (1996). Water in Ancient India. Indian Journal of History of Science, 31(4), 327-337.

Munandar, A. A. (2015). Keistimewaan Candi-candi Zaman Majapahit. Jakarta: Wedatama Widya Sastra.

Mundarjito. (1993). "Pertimbangan Ekologi dalam Penempatan Situs Masa Hindu-Buddha di Daerah Yogyakarta: Kajian Arkeologi-Ruang Skala Makro". Disertasi. Jakarta: Universitas Indonesia. 
Nareswara. (1993). "Pengertian dan Fungsi Petirtaan pada Masa Klasik di Jawa". Skripsi. Yogyakarta: Universitas Gadjah Mada.

Rahardian, P. H., \& Fery, W. C. (2015). "Kajian Arsitektur Percandian Petirtaan di Jawa (Identifikasi)". Laporan Penelitian. Bandung: Universitas Parahyangan.

Ramelan, W. D. S., H. santiko., H. Djafar, R. Maulana, W. D. sudjana. (2013). Candi Indonesia Seri Jawa. Jakarta: Direktorat Pelestarian Cagar Budaya dan Permuseuman.

Santiko, H. (2012). Candi Panataran: Candi Kerajaan Masa Majapahit. Kalpataru, 21(1), 20-29. https://doi.org/https://doi.org/10.24832/kpt.v21i1.103

Singh, R. P. B. (1994). Water Symbolism and Sacred Landscape in Hinduism: A Study of Benares (Vārāṇasī). Erdkunde, 4(3), 210-227. https://doi.org/https://www.jstor.org/stable/25646594

Sudaryati, N. L. G., \& Adnyana, I M. D. M. (2018). Pemanfaatan dan Makna Air dalam Veda. VIDYA WERTTA: Media Komunikasi Universitas Hindu Indonesia, 1(2), 107-116. https://doi.org/10.32795/vw.v1i2.194

Sumerata, I. W. (2013). Petirtaan Kuno di Banjar Bunyuh, Desa Perean. Forum Arkeologi, 26(3), $217-$ 224. https://doi.org/http://dx.doi.org/10.24832/fa.v26i3.46

Zoetmulder, P. J. (1994). Kamus Jawa - Kuno Indonesia. Jakarta: Gramedia Pustaka Utama.

Zulaikah, S. (2020). "Identifikasi Daerah Rawan Bencana Tanah Longsor Kabupaten Semarang Menggunakan Sistem Informasi Geografis Tahun 2019". Tugas Akhir Prodi D3. Semarang: Universitas Negeri Semarang. 
58 | The Implementation of Manasara-Silpasastra as...... Abednego Adhana Prakosajaya et. al. 